\title{
Utilization of bokasi solid organic fertilizer on corn plants (Zea mays, L) in Matang Seping Village, Aceh Tamiang
}

\author{
Desi Sri Pasca Sari ${ }^{1}$, Fauziansyah ${ }^{1}$, Akbaruddin ${ }^{1}$, Syariani Tambunan ${ }^{1}$, and Nico Syahputra Sebayang ${ }^{2^{*}}$ \\ ${ }^{1}$ University of Science Cut Nyak Dhien Langsa - Indonesia \\ ${ }^{2}$ University of Muhammadiyah Palembang - Indonesia \\ *Corresponding author: sebayangns@gmail.com
}

KEYWORDS

Bokasi Solid

Organic Fertilizer

Corn Plant

\begin{abstract}
This study aims to determine the effect of the dose of solid bokashi fertilizer and determine the best dose on the growth of maize (Zea mays L.). The research was carried out in Matang Seping Village, Kec. Banda Mulia, Kab. Aceh Tamiang. The time of the study was carried out from October to December 2019. This study used a Randomized Block Design (RAK), which was given treatment and was non-factorial. The dose factor of bokashi fertilizer with notation $(P)$, which consists of levels, namely: P0 = Without Bokashi, P1 = 200 grams, P2 = 300 grams, P3 = 400 grams. , 4th week and 6th week gave a significant effect on $\mathrm{P} 3$ treatment, namely at a dose of 400 grams/plant on the growth of plant height, stem diameter and number of leaves on corn (Zea mays L.).2.Use of solid bokashi fertilizer in the 2nd week, 4th week to 6th week can spur the growth of corn plants so that it has a significant effect on plant height, stem diameter and number of leaves on corn plants (Zea mays L.) in P3 treatment with a dose of 400 grams / plant.
\end{abstract}

(c) The Author(s) 2022

\section{INTRODUCTION}

Corn (Zea mays L.) is the second staple food after rice in Indonesia. Corn plants specifically are food crops that are very useful, both for human and animal life. Based on the order of staple foods in the world, maize also ranks third after wheat and rice. Until now, corn plants are used by the community in various forms of presentation, such as corn flour (maizena), corn oil, food ingredients, as well as animal feed and others (Pasta et al., 2015). One type of fertilizer that can be used is organic fertilizer. Organic fertilizers are fertilizers that consist entirely of organic materials derived from plant or animal waste that have gone through an engineering process used to supply organic matter to improve the physical, biological and chemical properties of the soil (Mulyanti et al., 2015). The use of such plant and animal waste needs to be carried out and increased in order to reduce the use of chemical-based fertilizers.

Another benefit that can be obtained from the use of bokashi fertilizer is that it can reduce the continuous use of inorganic fertilizers which will have a negative impact on soil fertility, plant growth, and the balance of soil microorganisms, creating plants that are rich in organic sources and can also reduce energy dependence (resources). nonrenewable nature) (Lestari et al., 2010). According to Sembiring et al. (2013), bokashi fertilizer is an organic fertilizer produced from the fermentation process or the fermentation of organic matter with EM-4 (Effective Microorganism4) technology. Effective Microorganism-4 is a mixed culture of various types of beneficial microorganisms such as synthetic bacteria, lactic acid bacteria, yeast, actinomycetes and fungi that can be used by inoculants to increase the diversity of microbes in the soil (?).

Raksun \& Mertha (2021) stated that the application of bokashi fertilizer had an effect on the growth of tomato plants on agricultural land in Pijot Village. The same thing was also stated by Mulyanti et al. (2015) about giving various types of bokashi fertilizer a very significant effect on the growth and yield of sweet corn, giving johar leaf bokashi gave better results on sweet corn growth, while giving gamal leaf bokashi gave better results. on sweet corn yields. Sources of bokashi fertilizer are very diverse, and can be obtained easily around housing, markets, and agricultural land. Gesriantuti et al. (2017) stated that materials that can be used in the manufacture of bokashi fertilizer can be in the form of vegetable waste, fruits, grass, legumes, husk charcoal, manure, and sawdust. However, the best material used for making bokashi is bran because it contains nutrients that are very good for the development of microorganisms. Based on the description above, it is necessary to conduct research to determine how the growth of corn (Zea mays $L$.) due to the application of solid bokashi fertilizer.

\section{METHOD}

The research was carried out in Matang Seping Village, Kec. Banda Mulia, Kab. Aceh Tamiang. The time of the study was carried out from October to December 2019. The materials that will be used in this research are as follows: $5 \mathrm{~kg}$ of cattle dung, $5 \mathrm{~kg}$ of husk charcoal, $5 \mathrm{~kg}$ of bran, $2 \mathrm{~kg}$ of 
dried leaves, $2 \mathrm{~kg}$ of banana stems, $2 \mathrm{~kg}$ of coconut fiber, 1 liter of clean water, EM-4 10 cc, Sugar 10 cc, Corn Seed (Bisi18 variety). The tools that will be used in this research are as follows: Hoe, Machete, Gembor, Measuring Cup, Scales, Cloth Meter, Bucket, Tarpaulin, Stationery

This study used a Randomized Block Design (RAK), which was treated and non-factorial.

$\mathrm{P} 0$ = No Bokashi, $\mathrm{P} 1=200$ grams, $\mathrm{P} 2=300$ grams, $\mathrm{P} 3$ $=400$ grams. Thus, 4 experimental treatments were obtained, each treatment was repeated 3 times so that 12 experimental treatments were obtained. The arrangement of experimental treatments can be seen in the following table: Arrangement of Experimental Treatments Without Bokashi and Bokashi

The observed data were then analyzed by means of variance using SPSS, then continued with the BNJ test at a level of $1 \%$ to $5 \%$ if there was a significant difference between the treatments. Experiment chart attached

\section{RESULTS AND DISSCUSION}

\subsection{Height of corn plant}

Observations on the dose of solid bokashi fertilizer on maize (Zea mays L.) were carried out when the plants were $2 \mathrm{WAP}, 3 \mathrm{WAP}, 4 \mathrm{MST}, 5 \mathrm{WAP}$ and $6 \mathrm{WAP}$. The variance test showed that the dose of fertilizer given had a significant effect on the height growth of maize (Zea mays L.). The average height of corn plants in each treatment can be seen in the following table 2.

In the table above, it can be seen that the height of corn (Zea mays L.) at the 2nd planting week, 4th planting week and 6th planting week showed the highest mean produced by P3 treatment, namely the application of solid bokashi fertilizer at a dose of 400 grams/day. plant. Meanwhile, the lowest value was shown in the 2nd planting week, 4th planting week and 6th planting week indicated at P0 treatment or no treatment at all (control). These results indicate that the application of bokashi fertilizer at a dose of 400 grams/plant gave a better effect in increasing the height of corn (Zea mays L.) until the 4 th week when compared to other treatments.

The application of solid bokashi fertilizer on corn plants has a significant effect on the height of corn plants. It is sus-

TABLE 1

\begin{tabular}{lc}
\hline $\begin{array}{l}\text { Treatment } \\
\text { Experimental }\end{array}$ & $\begin{array}{c}\text { Dosage of Bokashi Fertilizer } \\
\text { (grams/plant) }\end{array}$ \\
\hline $\mathrm{JP}_{0}$ U1 & No Bokashi \\
$\mathrm{JP}_{1}$ U1 & 200 \\
$\mathrm{JP}_{2}$ U1 & 300 \\
$\mathrm{JP}_{3}$ U1 & 400 \\
$\mathrm{JP}_{0}$ U2 & No Bokashi \\
$\mathrm{JP}_{1}$ U2 & 200 \\
$\mathrm{JP}_{2}$ U2 & 300 \\
$\mathrm{JP}_{3}$ U2 & 400 \\
$\mathrm{JP}_{0}$ U3 & No Bokashi \\
$\mathrm{JP}_{1}$ U3 & 200 \\
$\mathrm{JP}_{2}$ U3 & 300 \\
$\mathrm{JP}_{3}$ U3 & 400 \\
\hline
\end{tabular}

TABLE 2. Average Effect of Bokashi Fertilizer Dosage on Height of Corn Plants (Zea mays L.) (Note: The numbers followed by the same letter in the column show that they are not significantly different in the BNJ Test ( $0.05 \%$ level)

\begin{tabular}{lccc}
\hline & \multicolumn{3}{c}{ Plant Height (Week After Plant) } \\
\cline { 2 - 4 } Treatment & 2 & 4 & 6 \\
\hline$P_{0}$ & $7.00 \mathrm{a}$ & $30.67 \mathrm{a}$ & $54.67 \mathrm{a}$ \\
$P_{1}$ & $12.00 \mathrm{ab}$ & $40.00 \mathrm{ab}$ & $94.33 \mathrm{~b}$ \\
$P_{2}$ & $12.33 \mathrm{ab}$ & $42.33 \mathrm{~b}$ & $110.67 \mathrm{~b}$ \\
$P_{3}$ & $19.00 \mathrm{~b}$ & $56.00 \mathrm{c}$ & $157.00 \mathrm{c}$ \\
\hline
\end{tabular}

pected that by giving solid bokashi fertilizer to corn plants, it can indirectly increase photosynthetic activity in plants. Djunaedy (2009) stated that Effective microorganism-4 (EM4) contained in bokashi fertilizer has an important role in increasing photosynthetic bacteria and nitrogen-fixing bacteria in the soil. Giving bokashi fertilizer is also expected to increase nitrogen-fixing bacteria in the soil. Nitrogen is a very important element in the formation of chlorophyll which plays an important role in the plant growth process (Syifa et al., 2019).

Research by Novita \& Ruhukail (2011) on the use of EM4 cultured in bokashi fertilizer also had a significant effect on the growth of peanut plant height. This is because in bokashi fertilizer also contains fermenting microorganisms that can work effectively in fermenting (changing) organic materials so that they decompose quickly which are very useful for improving the physical, chemical and biological properties of the soil. The application of bokashi fertilizer into the soil is also expected to increase the content of organic matter and essential nutrients needed by plants.

\subsection{Corn plant stem diameter}

In the table above, it can be seen that the treatment with a dose of solid bokashi fertilizer on stem diameter of maize (Zea mays L.) at the 2nd planting week, 4th planting week and 6th planting week showed the highest mean in P3 treatment, namely with a dose of 400 grams/plant. Meanwhile, for the lowest value, observations were made on the stem diameter of corn plants which were carried out in the 2nd week, 4 th planting week and 6 th planting week indicated by the P0 treatment or control. Based on the data in Table 3 above, in general, the application of solid bokashi fertilizer to corn plants has a significant effect on the stem diameter of corn plants.

The results of the analysis of variance above prove that the application of solid bokashi fertilizer to corn plants can

TABLE 3. Average Effect of Dosage of Solid Bokashi Fertilizeron Stem Diameter of Corn Plants (Zea mays L.). (Note: The numbers followed by the same letter in the column show that they are not significantly different in the BNJ Test $(0.05 \%$ level)

\begin{tabular}{lccc}
\hline & \multicolumn{3}{c}{ Stem Diameter (Week After Plant) } \\
\cline { 2 - 4 } Treatment & 2 & 4 & 6 \\
\hline$P_{0}$ & $2.03 \mathrm{a}$ & $3.03 \mathrm{a}$ & $3.97 \mathrm{a}$ \\
$P_{1}$ & $2.33 \mathrm{a}$ & $3.97 \mathrm{a}$ & $4.77 \mathrm{~b}$ \\
$P_{2}$ & $2.43 \mathrm{a}$ & $4.17 \mathrm{ab}$ & $15.13 \mathrm{bc}$ \\
$P_{3}$ & $2.56 \mathrm{a}$ & $5.20 \mathrm{~b}$ & $5.90 \mathrm{c}$ \\
\hline
\end{tabular}


increase the continuity of nutrients in the soil so that they can be absorbed by plants to stimulate overall growth, especially in corn stalks. This is in accordance with the research of Permayani et al. (2020) on the effect of bokashi and Trichoderma varieties which showed a significant effect on the growth of stem diameter in corn plants. The growth of stem diameter in corn is thought to be inseparable from the high nitrogen content available for the needs of corn plants.

According to Mulyanti et al. (2015) the higher the dose of bokashi fertilizer given, the higher the nutrients received by the soil. Conversely, if the provision of nutrients is not sufficient, it will cause plant growth and development to be disrupted. This is due to the disruption of the formation of chlorophyll which is very important for the photosynthesis process for plants. Kastalani et al (2017) stated that the essential nutrients needed by plants include Nitrogen $(\mathrm{N})$, Phosphorus (P) and Potassium (K). The main role of nitrogen for plants is to stimulate the growth of plants as a whole, especially the stems and branches of plants.

Nitrogen also functions as a constituent of amino acids, protein components of chlorophyll pigments which are important in the process of photosynthesis. Likewise with phosphorus, besides playing a role in the process of photosynthesis, phosphorus also plays a role in stimulating root growth, seed formation and respiration. The fulfillment of the need for macro nutrients is thought to have an influence on the increase in stem diameter in corn plants. This is based on Retno \& Darminanti (2009) which states that sufficient nutrient content in the soil will cause the vegetative growth of corn plants to be good.

\subsection{Number of corn plant leaves}

TABLE 4. Average Effect of Dosage of Solid Bokashi Fertilizer on Number of Leaves of Corn Plants (Zea mays L.) (Note: The numbers followed by the same letter in the column show that they are not significantly different in the BNJ Test $(0.05 \%$ level)

\begin{tabular}{lclc}
\hline & \multicolumn{3}{c}{ Number of leaves (Week After Planting) } \\
\cline { 2 - 4 } Treatment & 2 & 4 & 6 \\
\hline$P_{0}$ & $3.66 \mathrm{a}$ & $6.33 \mathrm{a}$ & $7.67 \mathrm{a}$ \\
$P_{1}$ & $4.00 \mathrm{a}$ & $7.67 \mathrm{ab}$ & $10.00 \mathrm{ab}$ \\
$P_{2}$ & $4.33 \mathrm{a}$ & $8.00 \mathrm{~b}$ & $10.67 \mathrm{~b}$ \\
$P_{3}$ & $5.00 \mathrm{a}$ & $8.33 \mathrm{~b}$ & $11.00 \mathrm{~b}$ \\
\hline
\end{tabular}

The results of the analysis of variance above indicate that in general the treatment with a dose of solid bokashi fertilizer which has a higher number of leaves is the P3 treatment with (a dose of 400 grams/plant) which is indicated in the 2nd planting week, 4th planting week and 4th planting week. 6. As for the treatment, the lowest value of the dose of bokashi fertilizer on the number of leaves of corn plants (Zea mays L.) was in the P0 treatment or without treatment (control) both at the 2nd planting week, 4 th planting week to 6 th planting week. The variance test showed that the experimental treatment had a significant effect on the growth of the number of leaves on corn plants.

This shows that nitrogen and macronutrients contained in bokashi fertilizer affect the rate of leaf growth in corn plants. Permayani et al. (2020) stated the role of macro nutrients Nitrogen in bokashi and micro nutrients such as $\mathrm{Fe}, \mathrm{Mn}, \mathrm{Bo}, \mathrm{Mg}$ and so on in bokashi play a very important role in increasing protein, nucleic acid, green color and the amount of chlorophyll for the photosynthesis process. Besides that, macro and micro nutrients in bokashi also contain growth-promoting substances that can stimulate leaf growth. The same thing is also the case with research conducted by Kastalani et al. (2017) that the dose treatment of bokashi fertilizer showed a significant effect on the growth of the number of leaves on elephant grass (Pennisetum purpureum) plants.

The increase in nitrogen nutrients in the soil associated with the formation of chlorophyll in the leaves will result in an increase in the photosynthesis process which can spur the growth rate of the number of leaves in corn plants. Kastalani et al. (2017) stated that the role of phosphorus nutrients as an essential component of ADP and ATP which together also plays an important role in the process of photosynthesis and absorption of ions that can increase the number of leaves. In other words, the longer the age of the plant, it will provide the opportunity for the plant to grow longer so that the number of leaves produced will be more.

\section{CONCLUSIONS}

The application of solid bokashi fertilizer at the 2nd week, 4 th week and 6th week gave a significant effect and can stimulate the growth of corn plants on the P3 treatment, namely at a dose of 400 grams /plant on the growth of plant height, stem diameter and number of leaves on corn plants (Zea mays L.).

\section{References}

Budiyanto, Moch. A. K. (2011). Tipologi Pendayagunaan Kotoran Sapi Dalam Upaya Mendukung Pertanian Organik Di Desa Sumbersari Kecamatan Poncokusumo Kabupaten Malang. Gamma, 7(1), 42-49.

Dharma, P. A. W. Suwastika, A. A. N. G \& Sutari, N. W. S. (2015). Kajian Pemanfaatan Limbah Sabut Kelapa Menjadi Larutan Mikroorganisme Lokal. E-Jurnal Agroekoteknologi Tropika, 7, 200-210.

Djunaedy, A. (2009). Pengaruh Jenis dan Dosis Pupuk Bokashi Terhadap Pertumbuhan dan Hasil Kacang Panjang (Vigna sinensi L.). AGROVIGOR, 2(1), 42-46.

Gesriantuti N., Elsie, Harahap I., Herlina N., \& Badrun Y. (2017). Pemanfaatan Limbah Organik Rumah Tangga dalam Pembuatan Pupuk Bokashi di Kelurahan Tuah Karya, Kecamatan Tampan, Pekanbaru. JURNAL Untuk Mu negeRI, 1(1), 72-77.

Hartatik, W., Husnain, \& Widowati, L. R,. (2015). Peranan Pupuk Organik dalam Peningkatan Produktivitas Tanah dan Tanaman. Jurnal Sumberdaya Lahan, 9(2), 107-120.

Iinnaninengseh \& Ayuswastika, J. (2017). Respon Pertumbuhan Tanaman Lidah Mertua (Sansivera Sp) Yang dibudidaya Pada Jenis Media Tanam Tanah Berbeda Dengan Pemberian Pupuk Bokashi Hijauan Daun Kudo. Jurnal Ilmu Pertanian Universitas Al Asyariah, 2(2), 6171.

Isrun. (2010). Perubahan Serapan Nitrogen Tanaman Jagung dan Kadar Al-Dd Akibat Pemberian Kompos Tanaman Legum dan Nonlegum Pada Inseptisols Napu. J. Agroland, 17(1), 23-29. 
Kastalani, Kusuma, M., E., \& Melati, S. (2017). Pengaruh Pemberian Pupuk Bokashi Terhadap Pertumbuhan Vegetatif Rumput Gajah (Pennisetum purpureum). Ziraa'ah, 42(2), 123-127.

Kusuma, M. E. (2012). Pengaruh Beberapa Jenis Pupuk Kandang Terhadap Kualitas Bokashi. Jurnal Hewani Tropika, 1(2), 41-46.

Kusumawati, A. (2015). Analisa Karakteristik Pupuk Kompos Berbahan Batang Pisang. Seminar Nasional Universitas PGRI Yogyakarta.

Litbang. (2017). Pemanfaatan Sabut Kelapa Sebagai Sumber Kalium Organik. Warta, 23(1), 1-4.

Lestari, A. P, Sarman S, \& Indraswari, E. (2010). Subtitusi Pupuk Anorganik Dengan Kompos Sampah Kota Tanaman Jagung Manis (Zea mays saccharata Sturt). Jurnal Penelitian Universitas Jambi Seri Sains, 12(2), 01-06.

Muhadjir, F. (2018). Karakteristik Tanaman Jagung. Bogor. Balai Penelitian Tanaman Pangan Bogor.

Mulyanti, S. S., Made, U. \& Wahyudi, I. (2015). Pengaruh Pemberian Berbagai Jenis Bokashi Terhadap Pertumbuhan Dan Hasil Tanaman Jagung Manis (Zea mays Saccarata) e-J. Agrotekbis, 3(5), 592-601.

Muzayyanah. (2009). Pengaruh Pemberian Pupuk Bokashi Terhadap Pertumbuhan Tanaman Sawi (Brassica juncea L.). Skripsi. Fakultas Sains dan Teknologi. Universitas Islam Negeri Maulana Malik Ibrahim. Malang

Novita, L \& Ruhukail. (2011). Pengaruh Penggunaan EM-4 yang dikulturkan Pada Bokashi dan Pupuk Anorganik Terhadap Produksi Tanaman Kacang Tanah (Arachis hypogaea L) di Kampung Wanggar Kabupaten Nabire. Jurnal Agroforestri 4(2), 114-120.

Pasta, I., Ette, A., \& Baru, H. N. (2015). Tanggap Pertumbuhan Dan Hasil Tanaman Jagung Manis (Zea Mays L. Saccharata) Pada Aplikasi Berbagai Pupuk Organik. e-J. Agrotekbis, 3(2), 168 - 177.

Peraturan Menteri Pertanian Nomor 70/ Permentan/ Sr.140/ 10/ (2011). Tentang Pupuk Organik, Pupuk Hayati Dan Pembenah Tanah.

Permayani, I., Radian, \& Ramadhan, T., H. (2020). Pengaruh Beberapa Jenis Bokashi dan Trichoderma spp. Terhadap Pertumbuhan dan Hasil Tanaman Jagung Manis pada Tanah Alluvial. Agrovigor,13(1), 51-59

Raksun, A. \& Mertha A., I., G. (2021). Pengaruh Bokashi Terhadap Produksi Terong Ungu (Solanum Melongena L.). Jurnal Biologi Tropis, 18(1), 21-26.
Retno \& Darminanti, S. (2009). Pengaruh Dosis Kompos Dengan Stimulator Tricoderma Terhadap Pertumbuhan dan Produksi Tanaman Jagung (Zea mays L.).Varietas pioner-11 Pada Lahan Kering. Jurnal BIOMA, 11(2), $69-75$.

Safuan L. O. \& Hadini, H. (2012). Klasifikasi Genotip Jagung Lokal Asal Kabupaten Wakatobi Dan Kabupaten Bombana Berdasarkan Karakter Fenotipnya. Jurnal Agroteknos, 2(3), 126-133.

Sari, S. Y. (2015). Pengaruh Volume Pupuk Organik Cair Berbahn Dasar Sabut Kelapa (Cocos nucifera) Terhadap Pertumbuhan dan Hasil Panen Tanaman Sawi Hijau (Brassica juncea L.). Skripsi. Fakultas Keguruan dan Ilmu Pendidikan. Universitas Sanata Dharma. Yogyakarta.

Simanungkalit, F. D, Bangun M. K, \& Nuriadi, I. (2014). Respons Pertumbuhan Dan Produksi Beberapa Varietas Tanaman Jagung (Zea mays L.) Terhadap Pemberian Pupuk P Dan K. Jurnal Online Agroekoteknologi, 2(2), 813-824.

Suhastyo, A. A,. \& Setiawan, B. H,. (2017). Aplikasi Pupuk Cair Mol Pada Tanaman Padi Metode Sri (System Of Rice Intensification). Agritech, 19(1), 26-34

Supatra, I N. Y, Wijana, G. \& Adnyana, G. M. (2012). Aplikasi Jenis Pupuk Organik pada Tanaman Padi Sistem Pertanian Organik. E-Jurnal Agroekoteknologi Tropika, 1(2), $98-106$.

Suwardi \& Roy, E. (2009). Efisiensi Penggunaan Pupuk N Pada Jagung Komposit Menggunakan Bagan Warna Daun. Prosiding Seminar Nasional Serealia.

Sembiring, A. P., Bangun, M. K, \& Kardhinata, E. H. (2013). Pengaruh Pemberian Pupuk Bokashi dan Npk (15-1515) Terhadap Pertumbuhan dan Produksi Beberapa Varietas Tanaman Jagung (Zea Mays L.). Jurnal Online Agroekoteknologi, 1(2), 37-44.

Syifa', M., Amiroh, A, \& Suharso. (2019). Kajian Macam Bokashi dan Varietas Terhadap Pertumbuhan dan Produksi Tanaman Jagung (Zea mays L.). Agroradix, 2(2), 3243

Tufaila, M., Yusrina \& Syamsu Alam, S. (2014). Pengaruh Pupuk Bokashi Kotoran Sapi Terhadap Pertumbuhan Dan Produksi Padi Sawah Pada Ultisol Puosu Jaya Kecamatan Konda, Konawe Selatan. Jurnal Agroteknos, 4 No. 1. Hal 18-25.

Tjitrosoepomo, G. (2013). Taksonomi Tumbuhan (Spermatophyta). Gadjah Mada University Press. 